\title{
A PRACTICAL APPROACH FOR ESTIMATING INFLUENT- EFFLUENT MASS FLOW DIFFERENCES IN DAIRY MANURE-BASED ANAEROBIC CO-DIGESTION SYSTEMS
}

\author{
Rodrigo A. Labatut ${ }^{1}$, James W. Morris ${ }^{2, *}$, Curt A. Gooch ${ }^{2}$ \\ ${ }^{1}$ Department of Hydraulic and Environmental Engineering, Pontificia Universidad Catolica de Chile, Santiago, Chile. \\ 2 PRO DAIRY - Dairy Environmental Systems Program, Department of Animal Science, Cornell University, Ithaca, New York, 14853, United States. \\ *Correspondence: jwm87@cornell.edu
}

\section{HighLIGHTS}

- Three rigorous, methods for estimating influent-effluent mass flow differences due to biogas generation in manure-based anaerobic co-digestion systems are presented.

- The methods developed reveal that influent-effluent mass flow differences are driven by waste biochemical conversion - biogas water vapor content is insignificant.

- A simple, input-based method produced comparable results to two, more complex, output-based methods, when tested using 12 months of data collected from three dairy-based anaerobic co-digestion systems.

ABSTRACT. During co-digestion of dairy manure and off-farm organic waste in farm anaerobic co-digestion (AcoD) systems, the process's conversion of biodegradable organics to biogas reduces the volumetric mass (or mass-volume) of the effluent discharged compared to the mass-volume fed. In this study, we present three methods for estimating the mass-flow difference between influent and effluent due to conversion to biogas based on widely accepted, rigorously applied, biological and engineering principles. Monthly operating data from three full-scale AcoD systems, operated under different conditions for a full year were used to compare results using the three calculation methods. Results revealed that the predictions of influent mass flow loss obtained using a simplified input-based method primarily based on influent volumetric flow rates and biodegradability data were in good agreement with those obtained using more accurate, real-time data, namely methane concentration and biogas production. For AcoD systems adding off-site wastes at around $30 \%$ or less of the total influent volatile solids (VS), the estimated reduction in effluent flow was in the range of $3 \%$ or less. In one case, for VS additions up to approximately $60 \%$ of the AcoD system's influent load, the reduction was $12 \%$. Accepted fundamental water vapor relationships were also applied to biogas generation. Biogas water vapor loses were estimated to comprise approximately $0.2 \%$ of the total biogas mass-volume typically produced. Since in most anaerobic digestion systems, biogas condensate water is returned to the influent, this insignificant amount may be ignored.

Keywords. Anaerobic, Biogas, Co-digestion, Dairy manure, Digestion, Food waste, Volume-mass flow conversion.

$\mathrm{M}$ ost on-farm anaerobic digesters in the U.S. treat livestock manure from confined animal feeding operations (CAFOs). However, a growing number of on-farm digester operations co-digest manure with off-farm organics, mainly from the food-processing industry. Particularly in anaerobic codigestion (AcoD) systems, only a small portion of the influent stream consists of solid material; the vast majority is

c) (1) $\Theta$ The authors have paid for open access for this article. This (c) ${ }_{\mathrm{BY}} \mathrm{NC}_{\mathrm{ND}}$ work is licensed under a Creative Commons AttributionNonCommercial-NoDerivatives 4.0 International License https://creative commons.org/licenses/by-nc-nd/4.0/.

Submitted for review on 28 June 2020 as manuscript number NRES 14180; approved for publication as a Research Article by the Natural Resources \& Environmental Systems Community of ASABE on 11 January 2022. water (Labatut, 2013). Biogas is the result of decomposition of organic matter and evaporation of moisture. The digestible portion of the influent organic material is comprised of particulate and/or dissolved components with a wide array of physicochemical characteristics. The digestible particulate influent fraction is hydrolyzed to dissolved components which, along with the dissolved influent fraction, are primarily converted to methane $\left(\mathrm{CH}_{4}\right)$ and carbon dioxide $\left(\mathrm{CO}_{2}\right)$ gases through a series of biochemical reactions mediated by the anaerobic digester microbial community (Jeris and McCarty, 2008; Speece, 2008; Madigan et al., 2017). Also, depending on the elemental composition of the biodegradable organics present in the influent and the specific biochemical reaction pathways, a variable amount of molecular water will be either: 1) consumed from the reactor bulk liquid, 2) contributed to the reactor bulk liquid, or 3) may have no 
impact on reactor system water, as biogas is being generated by the anaerobic digestion process. Therefore, the stochiometric water balance contribution will depend on the aggregate elemental chemistry of the biodegradable portion of the influent (Symons and Buswell, 1933; McCarty, 1972). Furthermore, in vessel temperature impacts influent water evaporation. Thus, between conversion of biodegradable components and evaporation, a quantifiable portion of the influent mass leaves the digester as biogas. This amount depends on the influent characteristics and the operating conditions of the digester.

The vast majority of manure-based anaerobic digesters in the U.S. do not measure the effluent mass flow-moreover, it is usually, and mistakenly, assumed to be equal to the influent mass flow (which is rarely measured). According to the Law of Mass Conservation (Grady et al., 2011; Tchobanoglous et al., 2014), the portion of the influent converted to biogas will result in the reduction of effluent mass discharged. Accurate knowledge of effluent mass flow is particularly important in manure-based AcoD systems, as it is needed to: (1) forecast the produced residual biosolids for selling and/or bedding, (2) estimate the mass/concentration of nutrients (e.g., nitrogen, phosphorus, and potassium) available to crops when land-applied, and (3) size long-term post-digestion storages. In addition, the practice of off-farm, or third-party companies entering into business relationships with farm owners to provide AcoD systems is increasing. In a typical third-party arrangement, the non-farm entity provides the capital, operation, and management for the AcoD system in return for ownership of the energy generated or an agreed upon, typically major portion thereof. The entire digester effluent becomes the responsibility of the farm owner in nearly all cases. The farmer must responsibly store and apply effluent in accordance with their Comprehensive Nutrient Management Plan (CNMP). The cost of applying digestate associated with imported codigestion feedstocks is normally the responsibility of the offfarm entity. All farm operations, whether involved with offfarm third party entities or not, should understand the additional cost of applying digestate and the impact on their CNMP when considering accepting other wastes to co-digest in their system.

In the absence of digester effluent mass-flow meters, an accurate, yet simple method to adequately estimate the mass and volume of digestate discharged by an AcoD system can be useful. The mass and volume quantities considered for such estimates are directly related. Thus, with some care they embody the same concept and may be used in a unified manner as "mass-volume" as addressed in this present work. The theoretical basis for quantifying various mass-volume transformations occurring during anaerobic co-digestion as presented in this study, are elucidated in the broad microbiology, applied environmental science, and engineering literature. However, though widely known and accepted, these fundamentals have not been collected, reviewed, and presented into a summary of methods, and to the authors' knowledge, such an overall method summary has not yet been reported in the literature. Furthermore, the main goal of this study was to develop a simple method to estimate the biochemical conversion of organic influent into biogas, specifically aiming to determine the net mass flow difference between the digester influent and effluent, in a multi-feed stream anaerobic co-digestion (AcoD) system.

\section{Calculation Methods to Estimate MASS-VOLUME CONVERSION IN ANAEROBIC Digesters}

There is a need for a calculation method that can take advantage of the data commonly available in anaerobic digestion operations. A fundamental mass balance applying the Law of Mass Conservation around a typical continuously stirred anaerobic digester (CSAD) will be used to quantify feed stream conversion to biogas. This includes estimates of the biodegradability and thus conversion to biogas of the influent organics. The resulting mass-balance expressions are used to broadly describe the biochemical conversions occurring within the digester, and thus estimate the mass of influent leaving as biogas, thereby the mass-volume differences between the influent and the effluent of the CSAD.

To quantify the conversion of feed stream biodegradable solids and moisture to biogas, a straightforward empirical calculation framework is used. Two calculation approaches rely on digester biogas composition and generation data to determine the net fraction of feed stream conversion. One method relies on the molecular weight of components and the Ideal Gas Law (Tchobanoglous et al., 2014), and it is referred to as the Molar Method. A second method requires knowledge of the influent total solids (TS) and chemical oxygen demand (COD) - and it is referred to as the COD Method. To overcome the need for often unavailable operating output data, an alternative, simplified input-based method was developed. This method, referred to as the Biodegradability Method, is based on a semi-empirical calculation approach that only requires input data (feed stream characteristics) to predict the net fraction of influent mass removed (as above). Finally, since a portion of the digester influent also leaves the system as water vapor in the biogas, generally accepted empirical relationships will be used to estimate these mass-volume water vapor losses and their contribution to net influent reductions.

The three methods will then be validated, by comparing the influent mass removal estimates obtained, using data from three dairy operations receiving off-farm food wastes for co-digestion with the manure generated at their farms. Finally, the significance of water vapor losses and water impact of reactants and products stoichiometry based biochemical reaction results will be evaluated.

\section{INFLUENT CHARACTERIZATION}

The influent stream fed to an anaerobic digester is composed of several components of different characteristics which can be quantified by standard analytical techniques. Consider a series of analyses performed on the raw influent fed to an AcoD system (fig. 1). The total solids (TS) analysis drives off all the water if the sample is dried at $103^{\circ} \mathrm{C}$ to $105^{\circ} \mathrm{C}$ until a constant mass remains over time (APHA, 2005) (SM2540 B). The mass of materials remaining are referred to as dry matter or TS, SM2540 B refers to the specific standard method in (APHA, 2005). This subdivides the 
constituents of the raw influent into water, and both particulate and dissolved TS. Total solids are sub-divided into volatile solids (VS) and fixed solids (FS) by exposing the previously dried TS sample to $550^{\circ} \mathrm{C}$ until a constant weight is obtained (SM $2540 \mathrm{E}$ ). Volatile solids are typically considered to be organic. The materials remaining are considered to be inert or fixed solids (FS) sometimes referred to as ash. While FS are comprised of inert, un-digestible solids (e.g., sand, gravel, grit, soil inerts), VS make up the organic matter portion of the influent stream, a portion of which is available for biological uptake and conversion. The methanogenic biodegradable fraction $\left(f_{D}\right)$, in the case of anaerobic digesters, is determined by conducting the biochemical methane potential (BMP) assay (Owen et al., 1979). From the $f_{D}$ mass degraded, an equivalent mass of biogas is generated - a mixture of mostly $\mathrm{CH}_{4}$ and $\mathrm{CO}_{2}$ (fig. 1).

\section{Mass BaLANCE}

An appropriate configuration used for the treatment of complex, high-strength particulate wastes, including many AcoD operations, is the CSAD. CSADs minimize shock loads by continuously mixing and diluting the influent feed stream. A conceptual mass balance around a CSAD, which is essentially a continuously stirred tank reactor (CSTR) used as an anaerobic digester (Grady et al., 2011; Tchobanoglous et al., 2014), is shown in figure 2.

In a system mass balance analysis, the total influent mass $\left(\dot{m}_{\text {in }}\right)$ is accounted for by the flow mass of water, undigested solids, and metabolic products in the effluent $\left(\dot{m}^{\prime \prime}{ }_{\text {out }}\right)$, and the mass of gaseous products in the biogas $\left(\dot{m}_{\text {out }}^{\prime}\right)$ :

$$
\frac{d m}{d t}=\frac{d \rho}{d t} V=m_{\text {in }}-\left(\dot{m}_{\text {out }}^{\prime}+\dot{m}_{\text {out }}^{\prime \prime}\right)
$$

where, $m$ is the total mass in the $\operatorname{CSAD}(\mathrm{kg}) ; \rho$ is the density of the digestate in the CSAD $\left(\mathrm{kg} / \mathrm{m}^{3}\right) ; V$ is the volume of the liquid in the $\operatorname{CSAD}\left(\mathrm{m}^{3}\right) ; t$ is the reaction time (d); $\dot{m}_{i n}$ is the influent mass flow rate $(\mathrm{kg} / \mathrm{d}) ; \dot{m}_{\text {out }}^{\prime}$ is the biogas mass flow rate $(\mathrm{kg} / \mathrm{d}) ; \dot{m}^{\prime \prime}$ out is the effluent mass flow rate $(\mathrm{kg} / \mathrm{d})$.

The analysis assumes that physical and chemical processes, such as sedimentation and precipitation, are negligible, and no physical accumulation of solid material occurs inside the vessel. While accumulation of solids in many, if not most anaerobic digesters can be significant, especially in the longer term, for the analysis of these systems on a shortterm or intermediate timeframe, these accumulations are minimis. However, caution is to be exercised in digester

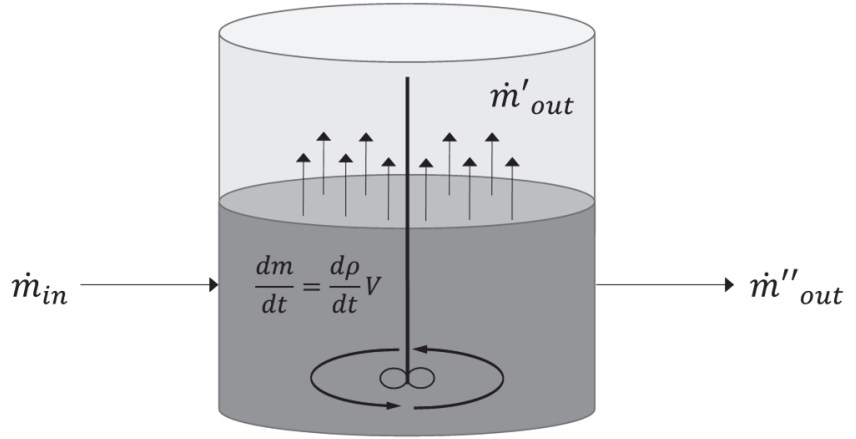

Figure 2. Mass balance around a continuously stirred anaerobic digester (CSAD); total influent mass $=\dot{m}_{i n}$, sum of constituents' mass in the liquid effluent $=\dot{m}^{\prime \prime}{ }_{\text {out }}$, and sum of biogas gaseous products' mass in the biogas $\left(\dot{m}^{\prime}\right.$ out $)$.

process analysis as both floating and settled solids can (and often do) accumulate within the reactor, resulting in a decrease of their active volume, and thus actual hydraulic retention times (HRT) and solid retention times (SRT). For analytical purposes, it is also assumed that acid-base and liquid-gas transfer equilibria as well as biochemical processes are at steady-state, that is, reactants and products, and mass in the liquid and gas phases are at equilibrium. Thus,

$$
\frac{d m}{d t}=\frac{d \rho}{d t} V=0
$$

in reality, transient accumulation of products is likely to occur due to the intrinsic variability of both influent flow volume and concentration observed in multiple-stream AcoD systems. Yet, over several HRT cycles, the process can be assumed to be at a pseudo-steady state, as products concentrations vary, but within a fairly constant, narrow range. Thus, equation 1 can be written as:

$$
\dot{m}_{\text {in }}=\dot{m}_{\text {out }}^{\prime}+\dot{m}_{\text {out }}
$$

The AcoD influent mass flow rate $\left(\dot{m}_{i n}\right)$ can be expressed as:

$$
\dot{m}_{\text {in }}=\rho_{\text {in }} Q_{i n(l)}
$$

where, $\rho_{i n}$ is the liquid density $\left(\mathrm{kg} / \mathrm{m}^{3}\right)$ and $Q_{i n(l)}$ is the volumetric flow rate $\left(\mathrm{m}^{3} / \mathrm{d}\right)$ of the $A$ coD influent.

If the liquid density and volumetric flow rate of the individual feed substances composing the influent stream are known, equation 4 becomes:



Raw substrate

Figure 1. General make up of influent (VS) fed to AcoD systems. The portion of the influent contributing to the vast majority of biogas $\left(\mathrm{CH}_{4}\right.$ and $\mathrm{CO}_{2}$ ) generated by the AcoD is the methanogenic biodegradable VS fraction, $f_{D}$. 


$$
\begin{aligned}
\dot{m}_{\text {in }}= & \sum_{i=1}^{n} \rho_{S(i)} Q_{S(i)}=\rho_{S(1)} Q_{S(1)} \\
& +\rho_{S(2)} Q_{S(2)}+\ldots+\rho_{S(n)} Q_{S(n)}
\end{aligned}
$$

where, $\rho_{S(i)}$ and $\mathrm{Q}_{S(i)}$ are the liquid density $\left(\mathrm{kg} / \mathrm{m}^{3}\right)$ and volumetric flow rate $\left(\mathrm{m}^{3} / \mathrm{d}\right)$ of the $i$ influent stream, respectively.

Also, if the influent is primarily composed of water (e.g., manure, whey, sewage), the liquid density, $\rho_{i n}$, can be calculated from the concentration and density of its solid constituents:

$$
\begin{aligned}
\rho_{i n} & =\frac{C_{W} \rho_{W}+\sum_{j=1}^{n} C_{T S(j)} \rho_{T S(j)}}{C_{W}+\sum_{j=1}^{n} C_{T S(j)}} \\
= & \left(C_{W} \rho_{W}+C_{T S(1)} \rho_{T S(1)}\right. \\
& \left.+C_{T S(2)} \rho_{T S(2)}+\ldots+C_{T S(n)} \rho_{T S(n)}\right) \\
& \div\left(C_{W}+C_{T S(1)}+C_{T S(2)}+\ldots+C_{T S(n)}\right)
\end{aligned}
$$

where, $\rho_{W}$ is the density of liquid water $\left(1,000 \mathrm{~kg} / \mathrm{m}^{3}\right) ; C_{W}$ is the water content $\left(\mathrm{kg} / \mathrm{m}^{3}\right)$ of the influent; $C_{T S(j)}$ and $\rho_{T S(j)}$ are the TS concentration $\left(\mathrm{kg} / \mathrm{m}^{3}\right)$ and density $\left(\mathrm{kg} / \mathrm{m}^{3}\right)$ of the solid constituent $j$ in the influent stream, respectively.

\section{BIOCHEMICAL SOLIDS CONVERSION}

Of the total VS in the influent, only $f_{D}$ can be potentially converted to biogas; thus, leaving the anaerobic digestion vessel, primarily as $\mathrm{CH}_{4}$ and $\mathrm{CO}_{2}$. $f_{D}$ represents the ratio between digestible organics and total organics, and can be expressed in terms of biomethane yield, chemical oxygen demand $(C O D)$, or $V S$ :

$$
f_{D}=\frac{B_{o}}{B_{u}}=\frac{C O D_{D}}{C O D}=\frac{V S_{D}}{V S}
$$

where, $B_{o}$ is the observed biochemical methane potential (BMP) measured in units of $\mathrm{L} \mathrm{CH}_{4} / \mathrm{g}$ VS fed; $B_{u}$ is the ultimate methane potential ( $\mathrm{L} \mathrm{CH}_{4} / \mathrm{g} \mathrm{VS}$ fed); $C O D_{D}$ is the biodegradable chemical oxygen demand of the influent stream (g COD/L); $C O D$ is the total chemical oxygen demand of the influent stream $(\mathrm{g} \mathrm{COD} / \mathrm{L}) ; V S_{D}$ is the biodegradable volatile solids of the influent stream (g VS/L); and, $V S$ is the total volatile solids of the influent stream $(\mathrm{g} \mathrm{VS} / \mathrm{L})$. Values for $C O D_{D}$ and $V S_{D}$ can be determined experimentally using anaerobic digestion tests, such as the BMP assay (Owen et al., 1979). The $C O D$ and $V S$ can be determined analytically (APHA, 1995), but the COD can also be determined using chemical reaction stoichiometry, if the chemical composition of the influent stream is known. Both $C O D$ and $V S$ ratios can be used to determine $f_{D}$; however, the $C O D$ basis is usually preferred because $\mathrm{CH}_{4}$ yields obtained via the BMP can be directly converted into $C O D$ equivalents.

Labatut et al. (2011) determined the basic physicochemical characteristics and assessed the BMP of several dairy manure samples and off-farm co-digestion mixtures commonly digested on-farm in New York State (table 1).
Table 1. Solids and COD concentration profile and methanogenic biodegradable fraction $\left(f_{D}\right)$ of various organic influent streams, as determined by Labatut et al. (2011); $f_{D}$ determined at mesophilic temperatures using the BMP assay.

\begin{tabular}{lcccc}
\hline Pure Influent Streams & $\begin{array}{c}\mathrm{TS} \\
(\mathrm{g} / \mathrm{L})\end{array}$ & $\begin{array}{c}\mathrm{VS} \\
(\mathrm{g} / \mathrm{L})\end{array}$ & $\begin{array}{c}\mathrm{COD} \\
(\mathrm{g} / \mathrm{L})\end{array}$ & $\begin{array}{c}f_{D}(\mathrm{~g} \text { COD } \\
\left.-\mathrm{CH}_{4} / \mathrm{g} \text { COD}\right)\end{array}$ \\
\hline Cabbage $(\mathrm{C})$ & 78.6 & 72.0 & 90.9 & 0.58 \\
Cheese whey (CW) & 78.7 & 66.8 & 125.6 & 0.64 \\
Corn leachate (CL) & 49.2 & 35.4 & 122.3 & 0.09 \\
Corn silage (CS) & 217.3 & 200.7 & 220.3 & 0.77 \\
Dairy manure (Mn) & 124.0 & 102.1 & 128.9 & 0.55 \\
Ice cream (IC) & 113.8 & 109.1 & 266.8 & 0.59 \\
Meat pasta (MP) & 381.8 & 340.6 & 562.8 & 0.37 \\
Potatoes (Pt) & 177.4 & 163.5 & 261.8 & 0.60 \\
Switchgrass (SG) & 930.1 & 904.9 & $1,327.4$ & 0.24 \\
Used vegetable oil (VO) & 991.0 & 988.8 & $2,880.0$ & 0.64 \\
\hline & & & & $f_{D}(\mathrm{~g}$ COD \\
Co-digestion Mixtures ${ }^{[a]}$ & $\mathrm{g} / \mathrm{kg}$ & $\mathrm{g} / \mathrm{kg}$ & $\mathrm{g} / \mathrm{kg}$ & $-\mathrm{CH}_{4} / \mathrm{g}$ COD) \\
\hline Mn75-CW25 & 68.5 & 57.7 & 100.3 & 0.41 \\
Mn75-MP25 & 148.5 & 136.9 & 233.0 & 0.48 \\
Mn75-SG25 & 308.0 & 284.4 & 413.6 & 0.41 \\
Mn75-VO25 & 263.6 & 235.4 & 922.0 & 0.26 \\
Mn90-CW10 & 83.2 & 68.4 & 103.2 & 0.45 \\
Mn90-MP10 & 101.9 & 89.8 & 151.2 & 0.39 \\
\hline [a] Numbers indicate the proportions (VS basis) between the co-digestion \\
$\quad$ influent streams & & & &
\end{tabular}

Analysis of manure samples obtained from six different dairy farms showed that $88 \%$ of the influent stream was composed of water, $12 \%$ total solids (particulate and dissolved solids combined), and $10 \%$ total VS; these values are in close agreement with the American Society of Agricultural and Biological Engineers - Engineering Practice Standards (ASABE Standards, 2013), and about 55\% of the VS were found to be digestible $\left(f_{D}\right)$. Thus, overall, only about $5.5 \%$ of the manure may potentially be anaerobically converted to biogas, assuming that the results of laboratory analyses apply to full-scale systems.

It is apparent that $f_{D}$ constitutes the most important parameter influencing the extent of solids conversion during anaerobic digestion, and thus represents the mass-volume removed from the influent stream. As expected, $f_{D}$ varies significantly among various dairy influent streams and codigestion mixtures due to the differences in the chemical composition of the constituent materials.

\section{EVAPORATIVE WATER LOSSES}

Water vapor is the third most prevalent biogas constituent after $\mathrm{CH}_{4}$ and $\mathrm{CO}_{2}$. Reported digester water vapor measurements ranged of from $5 \%$ to $7 \%$ for digesters operating at $35^{\circ} \mathrm{C}$ to $40^{\circ} \mathrm{C}$ (Ryckeboscha et al., 2011; Vardanjan et al., 2015; Kwaśny and Balcerzak, 2016). In a typical AcoD system, the digestate (comprised mostly of water) is intermittently or continuously mixed, and thus no solid crust formation on the digestate surface is expected. The presence of a crust would limit mass transfer between the digestate surface and the gas in the digester headspace. Thus, it can be assumed that the biogas within the anaerobic reactor headspace is saturated with water vapor, as reported elsewhere (Richards et al., 1991; Weiland, 2010; Strömberg et al., 2014). In the closed headspace of a digester, water vapor pressure and the concentration of water vapor follows absolute pressure and temperature relationships. Digester headspace pressure is typically 10 to $25 \mathrm{~cm}$ of water column, but 
it could reach up to $41 \mathrm{~cm}$ above atmospheric pressure (WEF/ASCE/EWRI, 2010).

It follows that absolute pressure is only a very small percentage $( \pm 2 \%)$ of one atmosphere. Thus, for the purposes of these calculations, the absolute pressure of the biogas in the digester head space is equal to standard atmospheric pressure. However, the biogas temperature changes according to the digester operating temperature and can impact on biogas moisture content. Richards et al. (1991) presented an empirical approximation to calculate the concentration of water vapor in biogas on a mass-volume $(\mathrm{m} / \mathrm{v})$ basis as a function of temperature:

$$
C_{H_{2} O_{(m)}}=0.05396 e^{(0.05808 T)}
$$

where, $C_{H_{2} O_{(m)}}$ is the water vapor concentration on a massvolume basis $\left(\mathrm{kg} / \mathrm{m}^{3}\right.$ biogas) and $T$ is the biogas temperature $\left({ }^{\circ} \mathrm{C}\right)$. The Richards et al. (1991) relationship was determined for temperatures between $15^{\circ} \mathrm{C}$ and $27^{\circ} \mathrm{C}$. Digesters addressed by this study operate in the mesophilic range $\left(35^{\circ} \mathrm{C}\right.$ to $40^{\circ} \mathrm{C}$ ).

A more general, alternative approach can be derived based on water vapor pressure relationships. Numerous empirical relationships to calculate the pressure of water vapor over liquid water have been developed over the years (Vömel, 2014). Three widely accepted equations are provided in table 2 .

From the water vapor pressure, the concentration of water vapor in biogas $(\mathrm{m} / \mathrm{v})$ can be obtained using the Ideal Gas Law, as follows:

$$
C_{\mathrm{H}_{2} \mathrm{O}_{(m)}}=\frac{P_{\mathrm{H}_{2} \mathrm{O}}}{R} \frac{M W_{\mathrm{H}_{2} \mathrm{O}}}{T+T_{\text {std }}}
$$

where, $M W_{\mathrm{H}_{2} \mathrm{O}}$ is the molecular weight of water $(18 \mathrm{~g} / \mathrm{mol})$; $R$ is the Universal Gas Constant $(0.082054 \mathrm{~L}-\mathrm{atm} / \mathrm{mol}-\mathrm{K}) ; T_{\text {std }}$ is the standard temperature in degrees Kelvin $\left(273.15^{\circ} \mathrm{K}\right)$.

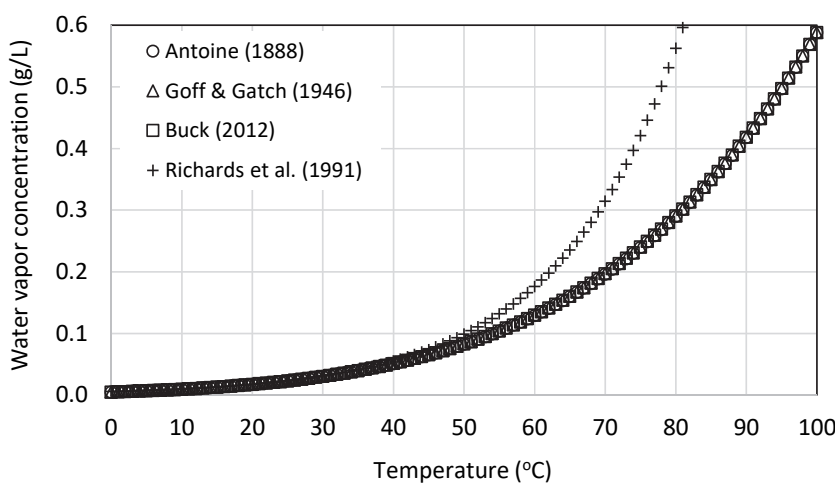

Figure 3. Water vapor concentration over liquid water surface (digestate) as a function of biogas temperature obtained using four different empirical equations.

To compare equations 8-11, the concentration of water vapor $\left(C_{H_{2} O_{(m)}}\right)$ over liquid water was calculated over the temperature range from $0^{\circ}$ to $100^{\circ} \mathrm{C}$ (fig. 3). The three equations, based on water vapor pressure shown in table 2 , produce almost identical results. However, for their simplicity and comparable accuracy, both Antoine (1888), which was later revised by Strömberg et al. (2014) and Buck (2012) equations, are preferred.

The concentration of water vapor in biogas can also be obtained on a volume-volume (v/v) basis using the Ideal Gas Law:

$$
C_{\mathrm{H}_{2} \mathrm{O}_{(v)}}=\left[\frac{C_{\mathrm{H}_{2} \mathrm{O}_{(m)}}}{M W_{\mathrm{H}_{2} \mathrm{O}}}\right]\left[\frac{R\left(T+T_{\text {std }}\right)}{P_{\mathrm{H}_{2} \mathrm{O}}}\right]
$$

where, $C_{H_{2} O_{(v)}}$ is the concentration of water vapor on a volume-volume basis $\left(\mathrm{m}^{3} / \mathrm{m}^{3}\right.$ biogas).

The effect of anaerobic digester operating temperature on biogas water vapor concentration was calculated using Buck's equation (eq. 11) on a m/v and $\mathrm{v} / \mathrm{v}$ basis (eqs. 12 and 13 , respectively) with results shown in table 3 . It was assumed that the digestate temperature is equal to the biogas

Table 2. Selected empirical equations used to calculate saturated water vapor pressure over liquid water surface.

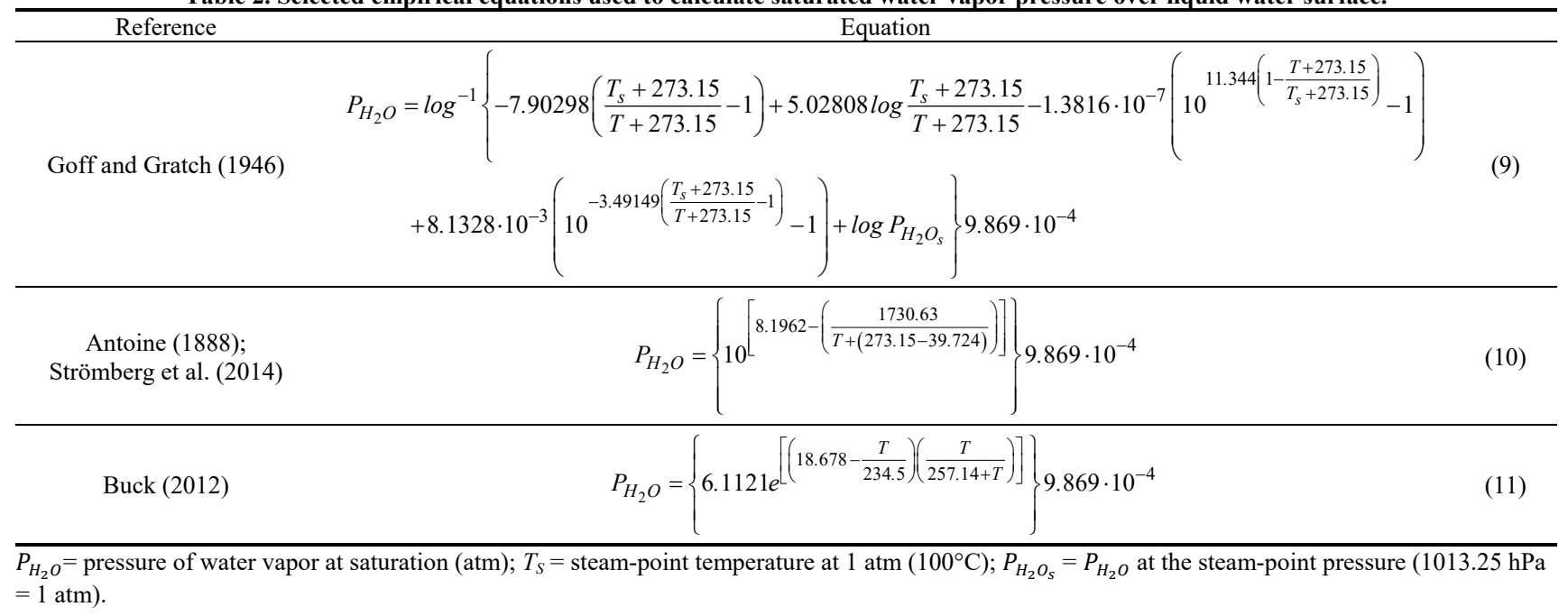


temperature. Note that water vapor discharged into the system's gas handling piping and appurtenances may condense and be collected, but it is equal to the mass of biogas water vapor discharged from the headspace for mass balance purposes. Many gas handling systems condense and collect water vapor, then add the condensate back into the digester effluent. As observed in table 3, water vapor concentration increases significantly with temperature; however, within the optimal temperature range for mesophilic organisms (i.e., $35^{\circ}$ to $40^{\circ} \mathrm{C}$ ), only between $0.004 \%$ and $0.005 \%$ of the biogas on a mass/volume basis corresponds to water. The actual extent of water mass loss via evaporation will depend on the rate of biogas production during anaerobic digestion. Still, the effect of water evaporation is apparent when considering the energy content of biogas. On a volume/volume basis, the concentration of water vapor in biogas can reach up to $7 \%$ within the mesophilic range, and nearly $20 \%$ within the thermophilic range (Ryckeboscha et al., 2011; Vardanjan et al., 2015; Kwaśny and Balcerzak, 2016).

\section{Net FraCtion OF INFLUENT MASS Biochemically CONVERTED TO BIOGAS}

The mass flow rate of biogas $\left(\dot{m}_{\text {out }}^{\prime}\right)$ is determined by the mass flow rate of water vapor $\left(\dot{m}_{\text {out }-W}\right)$ and the mass flow rate of organics converted to $\mathrm{CH}_{4}$ and $\mathrm{CO}_{2}$ gas $\left(\dot{m}_{\text {out }-C}{ }^{\prime}\right)$ leaving the CSAD. Thus,

$$
\begin{aligned}
\dot{m}_{\text {out }}^{\prime} & =\dot{m}_{\text {out }-W}^{\prime}+\dot{m}_{\text {out }-C}^{\prime} \\
& =C_{\mathrm{H}_{2} \mathrm{O}_{(m)}} Q_{\text {out }(g)}+\left(C_{\mathrm{CH}_{4}}+C_{\mathrm{CO}_{2}}\right) Q_{\text {out }(g)}
\end{aligned}
$$

where, $\mathrm{C}_{\mathrm{CH}_{4}}$ is the concentration of $\mathrm{CH}_{4}$ in the biogas $\left(\mathrm{kg} \mathrm{CH}_{4} / \mathrm{m}^{3}\right) ; C_{\mathrm{CO}_{2}}$ is the concentration of $\mathrm{CO}_{2}$ in the biogas $\left(\mathrm{kg} \mathrm{CO}_{2} / \mathrm{m}^{3}\right) ; Q_{\text {out }(g)}$ is the flow rate of biogas $\left(\mathrm{m}^{3}\right.$ biogas $\left./ \mathrm{d}\right)$. The water vapor concentration, $C_{H_{2} O_{(m)}}$, can be determined using equations 11 and 12 .

The net fraction of influent mass flow converted into the biogas stream is obtained by dividing equation 14 by the influent mass flow rate:

$$
\begin{aligned}
f_{\dot{m}_{\text {in }}} & =f_{\dot{m}_{w}}+f_{\dot{m}_{c}}=\frac{\dot{m}_{\text {out }-W}^{\prime}}{\dot{m}_{\text {in }}}+\frac{\dot{m}_{\text {out }-C}^{\prime}}{\dot{m}_{\text {in }}} \\
& =\frac{\dot{m}_{\text {out }-W}^{\prime}+\dot{m}_{\text {out }-C}^{\prime}}{\dot{m}_{\text {in }}}
\end{aligned}
$$

where, $f_{\dot{m}_{i n}}$ is the net fraction of influent mass flow converted (decimal); and, $f_{\dot{m}_{W}}$ and $f_{\dot{m}_{C}}$ are the fractions of water mass flow loss (decimal) and solids mass flow conversion (decimal), which are further defined as:

$$
\begin{gathered}
f_{\dot{m}_{w}}=\frac{C_{\mathrm{H}_{2} \mathrm{O}_{(m)}} Q_{\text {out }(g)}}{\dot{m}_{\text {in }}} \\
f_{\dot{m}_{c}}=\frac{\left(C_{\mathrm{CH}_{4}}+C_{\mathrm{CO}_{2}}\right) Q_{\text {out }(g)}}{\dot{m}_{\text {in }}}
\end{gathered}
$$

Output-based Methods to Predict $\boldsymbol{f}_{\dot{m}_{c}}$ Molar Method

The concentrations of $\mathrm{CH}_{4}$ and $\mathrm{CO}_{2}$ in equation 17 can be converted to a $\mathrm{m} / \mathrm{v}$ basis using the Ideal Gas Law:

$f_{\dot{m}_{c}}=$

$\left[\frac{\left(\mathrm{MW}_{\mathrm{CH}_{4}} \cdot P_{\mathrm{CH}_{4}}\right)+\left(\mathrm{MW}_{\mathrm{CO}_{2}} \cdot\left(1-P_{\mathrm{CH}_{4}}\right)\right.}{R \cdot T_{\text {std }}}\right] \frac{Q_{\text {out }(g)}}{\rho_{\text {in }} Q_{\text {in }(l)}}$

where, $M W_{\mathrm{CH}_{4}}$ is the molecular weight of $\mathrm{CH}_{4}(16 \mathrm{~g}$ $\left.\mathrm{CH}_{4} / \mathrm{mol}\right) ; P_{\mathrm{CH}_{4}}$ is the partial pressure of $\mathrm{CH}_{4}\left(\mathrm{~atm} \mathrm{CH}_{4}\right)$; $M W_{\mathrm{CO}_{2}}$ is the molecular weight $\mathrm{CO}_{2}\left(44 \mathrm{~g} \mathrm{CO}_{2} / \mathrm{mol}\right)$.

\section{COD Method}

Alternatively, $f_{\dot{m}_{c}}$ can be derived from the reaction stoichiometry for the complete oxidation of organic matter to $\mathrm{CH}_{4}$ that shows that $350 \mathrm{~m}^{3}$ of $\mathrm{CH}_{4}$ are yielded per $1,000 \mathrm{~kg}$ of $C O D$ stabilized (McCarty, 1964). Thus, equation 17 can also be expressed as:

Table 3. Concentration of water vapor and energy density of biogas as a function of temperature; shaded rows indicate optimal range for the different anaerobic digester process temperatures.

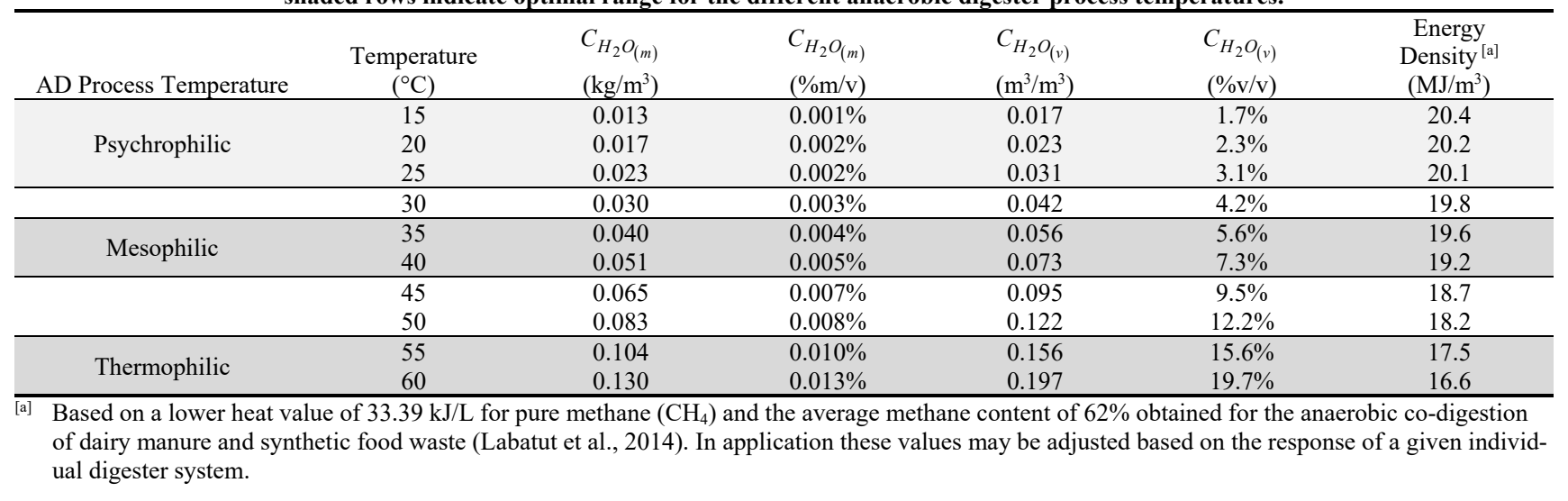




$$
f_{\dot{m}_{c}}=\left[\frac{P_{C H_{4}}}{P_{a b s}} \cdot \frac{C_{T S_{i n}}}{C_{C O D_{i n}}} \cdot 2.8571\right] \frac{Q_{\text {out }(g)}}{\rho_{\text {in }} Q_{\text {in }(l)}}
$$

where, $P_{a b s}$ is the absolute gas pressure inside the CSAD (about $1 \mathrm{~atm}$ ). Alternatively, the term $\frac{P_{\mathrm{CH}_{4}}}{P_{a b s}}$ is equivalent to the $\mathrm{CH}_{4}$ content of biogas (atm/atm,\%); $C_{T S_{i n}}$ is the influent total solids concentration; $C_{C O D_{i n}}$ is the influent chemical oxygen demand concentration $\left(\mathrm{mg} / \mathrm{L}=\mathrm{g} / \mathrm{m}^{3}\right) ; 2.8571 \mathrm{~g}$ $\mathrm{COD} / \mathrm{m}^{3} \mathrm{CH}_{4}$.

\section{Input-based Methods to Predict $\boldsymbol{f}_{\dot{m}_{\boldsymbol{c}}}$}

Equations 18 and 19 require output data from an operating anaerobic digester. Biogas production, with $\mathrm{CH}_{4}$ and $\mathrm{CO}_{2}$ concentration data from the operating anaerobic digester is needed. For systems without continuous data collection (e.g., SCADA), or for the design and planning of new AcoD projects, a method that does not require output data, is desired.

One such method may be based on the stoichiometry of the microbiologically-mediated reactions occurring in the anaerobic digester. Bioenergetics, along with some observations of the efficiency with which bacteria capture free energy, makes it possible to estimate cell yields and the overall stoichiometry associated with growth (McCarty, 1972), including the water consumed by the microbial process. Similarly, a stoichiometry-based equation to estimate methane yields and the major end products of fermentation based on the overall (or comprehensive mix) chemical composition of the influent being anaerobically digested was developed by Symons and Buswell (1933). The equation, also known as the Buswell Formula, simply represents a balanced redox reaction where the primary products of anaerobic digestion are methane, carbon dioxide, and ammonia:

$$
\begin{aligned}
& \mathrm{C}_{n} \mathrm{H}_{a} \mathrm{O}_{b} N_{c} \\
& +\left[n-\frac{a}{4}-\frac{b}{2}+\frac{3 c}{4}\right] \mathrm{H}_{2} \mathrm{O} \rightarrow\left[\frac{n}{2}-\frac{a}{8}+\frac{b}{4}+\frac{3 c}{8}\right] \mathrm{CO}_{2} \\
& +\left[\frac{n}{2}+\frac{a}{8}-\frac{b}{4}-\frac{3 c}{8}\right] \mathrm{CH}_{4}+c \mathrm{NH}_{3}
\end{aligned}
$$

Water's role in the conversion of organic matter to biogas is determined by equation 20. This stoichiometric reactants and products relationship for a known biodegradable feed molecule (or mix) determines whether a specific biogas generating reaction: 1) requires or consumes reactor bulk liquid water, 2) produces or contributes bulk liquid water, or 3) may have no impact on reactor system water during anaerobic digestion process. However, as with the method of McCarty, the Buswell Formula not only requires a detailed chemical composition of the organics contained in the influent stream, but also their biodegradability, which makes these methods difficult to implement in practical situations.

Similarly, complex mechanistic/dynamic models, such as the Anaerobic Digestion Model No. 1 (ADM1), also require detailed data for the influent stream and operating parameters for the anaerobic digestion system (Batstone et al., 2002;
IWA Task Group for Mathematical Modelling of Anaerobic Digestion Processes, 2002). On the other hand, this study presents a straightforward semi-empirical calculation approach, specifically targeted to predict the net fraction of influent solids mass flow converted into biogas in manurebased AcoD systems. Certainly, the proposed calculation approach is not as robust as ADM1, but rather is system specific, relying on basic system input data, either actual or estimated from pertinent references.

\section{Biodegradability Method}

This method is based on the BMP studies performed by Labatut (2012) to evaluate the anaerobic co-digestion of dairy manure and food wastes under various food waste to manure co-digestion ratios. This study used a synthetic food waste to simulate the multi-component properties of a foodlike waste, and to produce composition-based results, thereby not limited to any particular waste and suitable for modelling purposes. Labatut (2012) reported that $f_{D}$ followed a linear relationship $\left(\mathrm{R}^{2}=0.97\right.$ and a low standard error - SE $=0.04$ ) with increased proportions of constant composition food waste in the manure-based co-digestion influent. The following regression equation was obtained:

$$
f_{D}=0.46 R_{F W}+0.51
$$

where, $R_{F W}$ is the food waste co-digestion ratio on a $V S$ basis (decimal) (i.e., the proportion of food waste in the influent), as defined by:

$$
R_{F W}=\frac{\sum_{i=1}^{n} C_{V S_{F W(i)}}}{C_{V S_{i n}}}
$$

where, $C_{V S_{F W}}$ is the added concentration of all food wastes in the influent on a $V S$ basis $\left(\mathrm{kg} \mathrm{VS} / \mathrm{m}^{3}\right)$ and $C_{V S_{i n}}$ is the influent VS concentration $\left(\mathrm{kg} / \mathrm{m}^{3}\right)$. Equation 21 indicates the extent of VS conversion, as determined by BMP assay. To estimate continuous, steady-state performance of an anaerobic digester, it is necessary to account for the kinetics of both microbial growth and influent organics utilization. The equation developed by Chen and Hashimoto (1980) based on Contois kinetics can be used to describe the kinetics of $\mathrm{CH}_{4}$ production as a function of the operating temperature and the HRT of a CSAD at steady-state conditions:

$$
B=B_{o}\left(1-\frac{K}{\mu_{m} H R T-1+K}\right)
$$

where $B$ is the steady-state $\mathrm{CH}_{4}$ production $\left(\mathrm{m}^{3} \mathrm{CH}_{4} / \mathrm{kg} V S\right.$ added); $B_{o}$ is the maximum $\mathrm{CH}_{4}$ production $\left(\mathrm{m}^{3} \mathrm{CH}_{4} / \mathrm{kg} V S\right.$ added); $K$ is the dimensionless kinetic parameter; $\mu_{m}$ is the maximum specific growth rate of microorganisms $\left(\mathrm{d}^{-1}\right)$. Chen (1983) developed two other equations to describe $\mu_{m}$ as a function of temperature and $K$ as a function of the influent $V S$ concentration as related to process inhibition:

$$
\mu_{m}=0.013 T-0.129
$$




$$
K=0.6+0.0006 e^{\left(0.1185 \cdot C_{V S_{i n}}\right)}
$$

Multiplying equation 23 by $C_{V S_{i n}}$ and dividing by $B_{u}$ and $\rho_{\text {in }}$ results in:

$$
\frac{B}{B_{u}}=\frac{B_{o}}{B_{u}} \frac{C_{V S_{i n}}}{\rho_{\text {in }}}\left(1-\frac{K}{\mu_{m} H R T-1+K}\right)
$$

where, $B_{o} / B_{u}$ is equal to $f_{D}$ (eq. 21 ) and $B / B_{u}$ is equivalent to $f_{\dot{m}_{c}}$, so equation 26 becomes:

$$
f_{\dot{m}_{c}}=f_{D} \frac{C_{V S_{i n}}}{\rho_{\text {in }}}\left(1-\frac{K}{\mu_{m} H R T-1+K}\right)
$$

In addition, if the influent $C O D$ concentration is known, the flow rate of biogas $\left(Q_{\text {out }(g)}\right)$ can be derived from equation 26:

$$
\begin{aligned}
& Q_{\text {out }(g)}= \\
& 2.8571 \frac{f_{D} C_{C O D_{i n}} Q_{i n(l)} P_{a b s}}{P_{C H_{4}}}\left(1-\frac{K}{\mu_{m} H R T-1+K}\right)
\end{aligned}
$$

Equation 28 allows using input data to determine the average flow rate of biogas, which is required to calculate the fraction of water mass loss, $f_{\dot{m}_{w}}$ (eq. 16). The methane content in equation 28 , represented by the term $\frac{P_{\mathrm{CH}_{4}}}{P_{a b s}}$, can be assumed to be $62 \%$, which is the average ( $\mathrm{SD}=0.9 \%$ ) obtained by Labatut et al. (2014) at steady-state from a labscale manure-based AcoD system adding synthetic food waste at two distinct co-digestion ratios (i.e., $25 \%$ and $75 \%$ ). This is a reasonable assumption, considering that $f_{\dot{m}_{w}}$ contributes less than $5 \%$ (mass/mass) to the net influent mass removal, as discussed below. A plot of influent $V S$ concentration $\left(C_{V S_{i n}}\right)$ versus fraction of solids mass flow conversion $\left(f_{\dot{m}_{c}}\right)$ was constructed using equation 27 , based on a fixed HRT of 30 days and an operating temperature of $37^{\circ} \mathrm{C}$ (fig. 4). It is apparent from the plot that, the higher the portion of food waste in the influent or higher the co-digestion ratio, (i.e., higher $R_{F W}$ ), the higher the fraction of solids mass flow converted for the cases considered in this study. This is expected due to the comparatively higher biodegradability of food waste compared to that of dairy manure. The organic material in manure has already been subjected to digestion in the cow's rumen and digestive track leaving a residual material resistant to further digestion and much higher in recalcitrant lignin content (Labatut, 2012).

For example, the influent of a manure based AcoD system adding $35 \%$ food waste (VS basis) and with a total influent VS concentration of $11 \%,\left(110 \mathrm{~kg} \mathrm{VS} / \mathrm{m}^{3}\right)$ will undergo a calculated solids mass conversion of $7 \%$ (mass $/ \mathrm{mass}$ ). Also, equation 26 was used to assess the influence of HRT on solids mass flow conversion as a function of the co-digestion

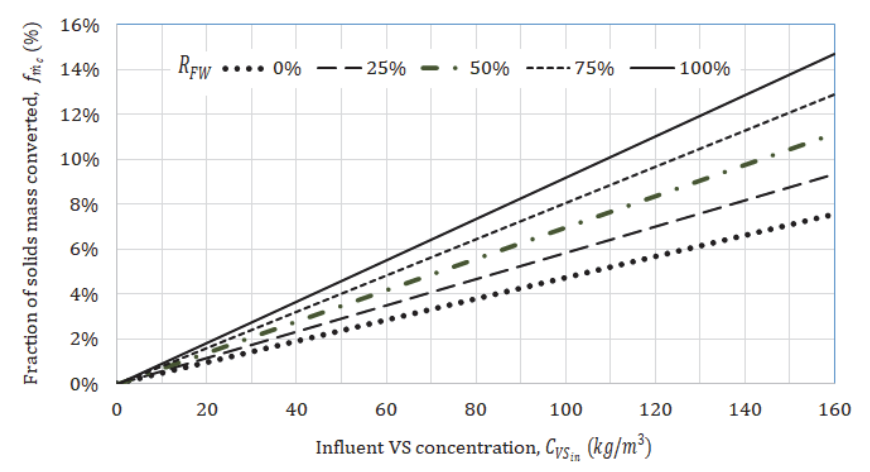

Figure 4. Fraction of solids mass flow converted (\%) as a function of influent VS concentration $\left(\mathrm{kg} / \mathrm{m}^{3}\right)$ and co-digestion ratio (i.e., $0,25 \%$, $50 \%, 75 \%$, and $100 \%$ - VS basis) for a CSAD operated at a 30-d HRT and $37^{\circ} \mathrm{C}$.

ratio at a fixed influent $V S$ concentration. Figure 5 portrays this relationship for a VS concentration of $80 \mathrm{~g} \mathrm{VS} / \mathrm{L}$ typical for many manure-based systems. As shown, the most significant effect of the HRT on the fraction of solids mass flow conversion is for HRTs under 10 days. However, for HRTs between 10 and 30 days, the difference could be as high as $0.6 \%$, which, for a typical AcoD system receiving an influent of 400 tons per day, translates into over three extra tons of effluent per day. Real AcoD systems receiving several different co-digestion influent streams could have even larger differences in the fraction of solids mass flow conversion because of the variable HRTs and organic loading rates (OLRs). This is the case of the Synergy Digester in New York State, a facility that received over 12 different wastes, resulting in an HRT that, throughout a year varied from 22 to 43 days (Labatut and Gooch, 2014).

Once the fraction of water mass flow loss $\left(f_{\dot{m}_{w}}\right)$ and the fraction of solids mass flow conversion $\left(f_{\dot{m}_{c}}\right)$ are known, the biogas mass flow rate $\left(\dot{m}_{\text {out }}^{\prime}\right)$ can be obtained using equation 14. Then, $\dot{m}_{\text {out }}{ }$ is subtracted from the influent mass flow rate $\left(\dot{m}_{i n}\right)$ to obtain the effluent mass flow rate ( $\dot{m}^{\prime \prime}{ }_{\text {out }}$ ), as follows:

$$
\dot{m}^{\prime \prime}{ }_{\text {out }}=\dot{m}_{\text {in }}-\dot{m}_{\text {out }}^{\prime}=\dot{m}_{\text {in }}-\dot{m}_{\text {in }} \cdot\left(f_{\dot{m}_{w}} \cdot f_{\dot{m}_{c}}\right)
$$

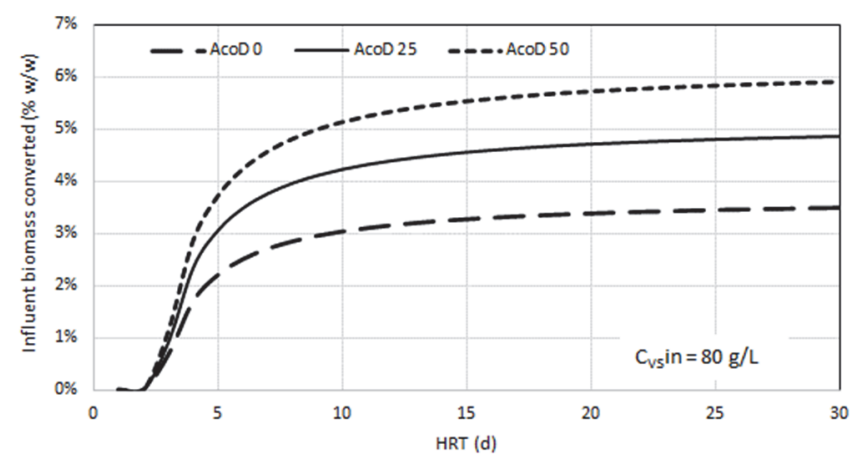

Figure 5. Fraction of solids mass flow conversion (\%) as a function of HRT for manure only and two co-digestion ratios (i.e., 25 and $50 \%$ $V S$ basis) for a CSAD operated at an influent $V S$ concentration of $80 \mathrm{~g} / \mathrm{L}$ and $37^{\circ} \mathrm{C}$. 
Also, the influent material and the volumetric flow rate of biogas can be expressed by replacing $\dot{m}_{\text {in }}$ and $\dot{m}^{\prime}{ }_{\text {out }}$ by equation 5 and equation 14 , respectively:

$$
\begin{aligned}
& \dot{m}^{\prime \prime}{ }_{\text {out }}=\dot{m}_{\text {in }}-\dot{m}_{\text {out }}^{\prime} \\
& =\sum_{i=1}^{n} \rho_{S(i)} Q_{S(i)}-\left(C_{\mathrm{H}_{2} \mathrm{O}_{(m)}}+C_{\mathrm{CH}_{4}}+C_{\mathrm{CO}_{2}}\right) Q_{\text {out }(g)}
\end{aligned}
$$

Equation 30 provides an effluent mass flow rate comparable to that determined by the direct measurement of the digester's effluent liquid density and volumetric flow rate:

$$
\dot{m}^{\prime \prime}{ }_{\text {out }}=\rho_{\text {out }} Q_{\text {out }(l)}
$$

Finally, the effluent volumetric flow rate $\left(Q_{\text {out }(l)}\right)$ can be obtained by dividing in " ${ }_{\text {out }}$ by the effluent liquid density $\left(\rho_{\text {out }}\right)$.

\section{DISCUSSION}

When online biogas production and methane content data are available, equation 18 is the preferred method to estimate the fraction of solids mass flow conversion $\left(f_{\dot{m}_{c}}\right)$ because standard gas meters and electrochemical sensors to measure methane and carbon dioxide are accurate, if calibrated and properly maintained. However, when continuously collected output data is not available, the simplified, input-based Biodegradability Method, is a convenient and reliable option to predict the approximate fraction of influent mass flow loss of an AcoD system (eq. 27).

Validation of the input-based, Biodegradability Method is performed by comparison to results obtained using the two output-based methods (i.e., COD and Molar basis). The COD and Molar basis methods (eqs. 18 and 19) are deemed to be accurate, not only because they are based on actual output data from the operating AcoD system, but also because the data used for this validation was measured continuously. Validation data came from a comprehensive 12-month sampling-monitoring program conducted at three operating AcoD systems on combined animal feeding operation (CAFO) dairies located in central western New York State, noted herein as Farm 1, Farm 2, and Farm 3 (Gooch et al., 2011). The feed stream and digester effluent were sampled every 15 days for a 2-year period, along with continuous monitoring of system loading and biogas volume generated with analysis of their key characteristic parameters. The report provides the sampling and analysis protocol followed during this extensive study. The influent feed stream to the Farm 1 and Farm 2 AcoD systems consisted of approximately $23 \%$ and $29 \%$ food waste, respectively. In contrast, Farm 3 influent had a considerably higher food waste content at about $60 \%$ food waste during the period evaluated.

Data for the three farm systems were used to estimate the component total system mass losses. Evaporative losses were addressed using the Buck's Equation (11), and massvolume reductions applying the Molar (eq. 18), COD (eq. 19) and Biodegradable (eq. 27) basis calculation methods. Estimate results for the data sets from all three farms are shown in figure 6.

In terms of the average fraction of influent solids mass flow loss over the 12-month period, the three methods produced comparable results for the three AcoD systems, with differences that generally fall within the observed standard deviations shown. Coefficient of variations indicated that standard deviations were as high as $53 \%$ of the mean influent solids mass flow loss, as in the case of Farm 2 using the COD method. The main source of such large deviations is the variation of the measured data during the 12-month monitoring period. As an example, compare the mass flow reduction predicted by the three methods for Farm 1 as plotted in figure 7. As shown, the estimates obtained can result in differences as high as $2 \%$ in the influent solids mass flow loss values.

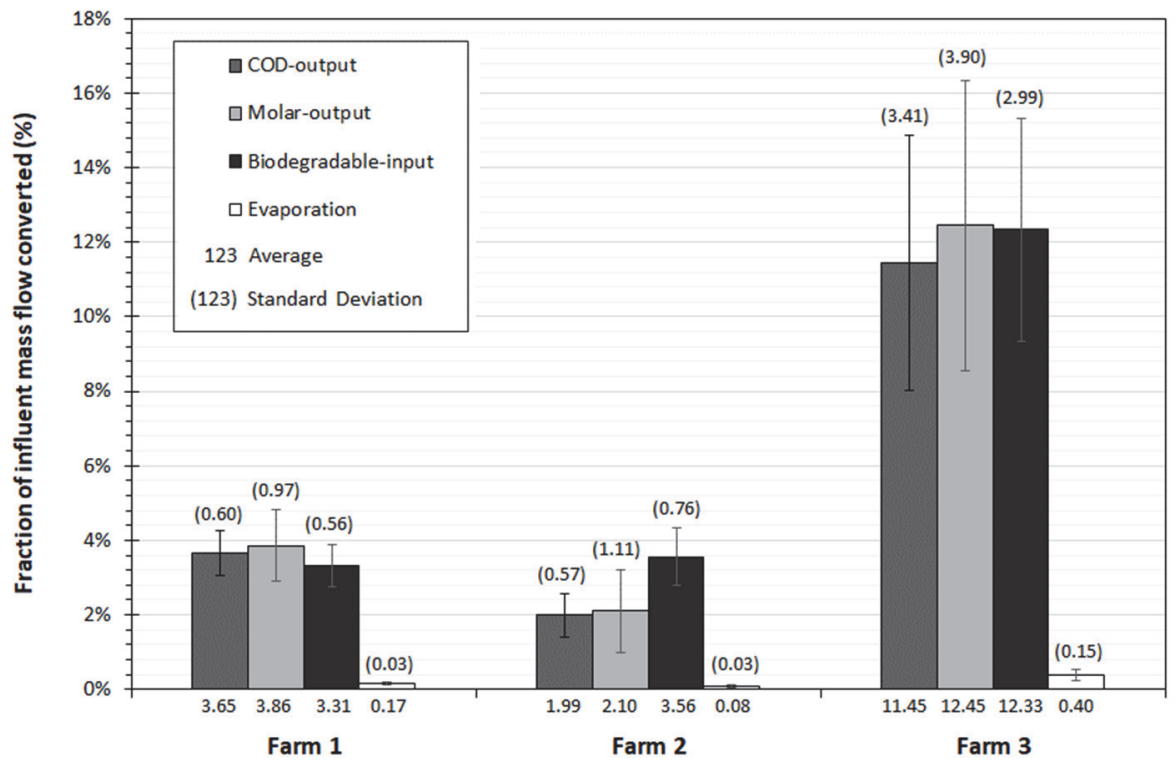

Figure 6. Prediction of influent feed stream mass-volume removal via organic matter conversion and water evaporation (\%) for three full-scale on-farm AcoD systems using three calculation methods. 


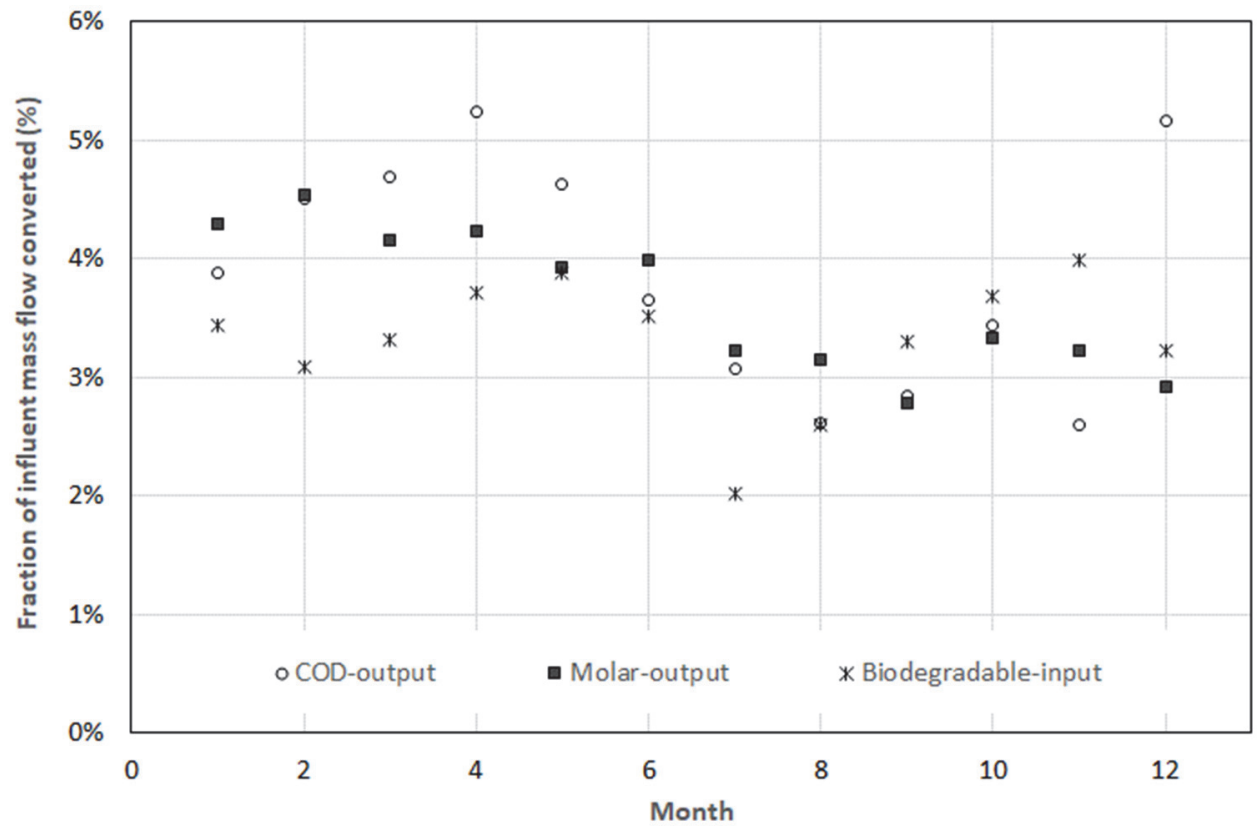

Figure 7. Fraction of influent mass flow conversion (\%) as predicted by two output methods and the Biodegradable, input-based method during the 12-month monitoring for Farm 1.

The root mean square error test (RMSE) may also be used to assess the agreement between the estimation methods.

$$
R M S E=\sqrt{\frac{\sum_{i=1}^{n}\left(P_{i}-O_{i}\right)^{2}}{n}}
$$

where, $\mathrm{n}$ is the number of data points, $P \mathrm{i}$ is the i predicted input-based estimate data, and $O \mathrm{i}$ is the i output-based data (Chai and Draxler, 2014). Despite the marked influent mass flow loss variations experienced, the root mean square error (RMSE) calculated from the results of the input and outputbased methods were relatively low, with values that ranged from 0.008 to $0.011,0.016$ to 0.017 , and 0.041 to 0.046 , for Farms 1, 2, and 3, respectively.

Although, a significantly higher fraction of influent solids mass flow loss was predicted by the Biodegradable basis method for Farm 2, this method showed a standard deviation comparable to the output methods (fig. 6). These results constitute good agreement, considering that the COD and Molar output-based methods used continuous biogas data and daily methane and carbon dioxide data, whereas the Biodegradable based method used information from just a single monthly influent characterization. This is particularly true considering the inherent difficulty of measuring the continuous long-term mass-flow influent.

The relatively large difference in the predicted average fraction of influent solids mass flow loss for Farms 1 and 2 relative to Farm 3 (i.e., $\sim 3 \%$ vs. $\sim 12 \%$ ) is consistent with the co-digestion ratios $\left(R_{F W}\right)$ of each of these AcoD systems. While the average influent of Farms 1 and 2 consisted of $28 \%$ and $30 \%$ (VS basis) food waste, respectively, the influent of Farm 3 consisted of $60 \%$ food waste during the evaluated period. This confirms the direct relationship between the proportion of food waste to influent stream, the biodegradability of the influent stream, and the resulting fraction of influent solids mass flow loss for this study.

Evaporative losses were also estimated using equation 11 from the 12-month data sets of all three farm AcoD systems (fig. 6). On average from these three cases, evaporation mass losses calculated contributed only about $0.2 \%$ to the net fraction of influent mass flow converted.

As previously noted, the two output-based methods (eqs. 18 and 19) are deemed to be accurate, not only because they are based on actual output data from the operating AcoD systems, but also because the data used were measured continuously. In terms of the average fraction of influent solids mass removed over the 12-month period, the three methods produced comparable results for Farm 1 and Farm 2, with an average influent mass-volume conversion $\left(f_{\dot{m}_{i n}}\right)$ at approximately $3.1 \%$. The standard deviation bars shown for each method represents the data variation of $f_{\dot{m}_{i n}}$ throughout the 12-month monitoring period (fig. 6). This constitutes good agreement, considering that the COD and Molar output-based methods used continuous biogas data and daily $\mathrm{CH}_{4}$ and $\mathrm{CO}_{2}$ data, whereas the Biodegradable based method used information from just a monthly average influent characterization. Estimated influent mass-volume conversion for Farm 3, for the three calculation methods, were also consistent. The higher food waste portions loaded into the AcoD resulted in higher overall change in mass between the liquid influent and liquid effluent at an average of about $12 \%$. On average, for the three cases, evaporation mass losses calculated using equations 11 and 12 only contributed an average of around $0.2 \%$ to the net influent feed stream mass removal. 


\section{CONCLUSiOnS}

Three methods detailed are based on widely accepted, rigorously applied, biological and engineering principles for estimating the mass-flow difference between influent and effluent due to biomass to biogas conversion. A relatively simple Biodegradability approach, that uses influent volumetric flow rates and biodegradability characterizations of the individual co-digestion streams, is recommended as a practical application that provides reasonable estimates of acceptable accuracy. Estimates using the recommended approach rely on information typically measured or readily obtained to provide estimates with acceptable accuracy for design, operation and by-product utilization of manurebased AcoD systems. It has been shown that rigorous estimates of mass flow conversions in AcoD systems require the quantification of water evaporative losses and the conversion of influent organic materials leaving the system in the biogas produced. As presented, the Buck (2012) empirical model (eq. 11) can be used together with equation 12 to accurately estimate the fraction of water mass flow loss $\left(f_{\dot{m}_{w}}\right)$

(eq. 16) in the biogas generated. A simple empirical calculation framework, applied to assess biochemical solids conversion in AcoD systems, has also been presented. As shown, two calculation approaches based on fundamental principles (eqs. 18 and 19) rely on continuous output data from an operating AcoD system, namely biogas production, and methane and carbon dioxide gas content, to determine the fraction of solids mass flow conversion $\left(f_{\dot{m}_{c}}\right)$. Since continuously collected output data are not always available, an alternative, simplified, biodegradability-based method based on a semi-empirical calculation approach that only requires input data to predict the fraction of solids mass flow conversion $\left(f_{\dot{m}_{c}}\right)$, was developed (eq. 26). Using both, equations 16 and 27 it is possible to estimate the net fraction of influent mass flow conversion $\left(f_{\dot{m}_{i n}}\right)$ in an AcoD system (eq. 15). Finally, the effluent mass flow rate is obtained by using equation 30 .

In summary, consider the three estimation calculation techniques presented. The Molar Method requires biogas flow rate and $\mathrm{CH}_{4}$ content data to be collected. In most AcoD operations, biogas production is measured continuously, but $\mathrm{CH}_{4}$ and $\mathrm{CO}_{2}$ content are measured rather sporadically. Yet, considering that $\mathrm{CH}_{4}$ concentration does not change significantly in well-operated digesters and provided that biogas flow meters and gas sensors are calibrated and maintained appropriately, this method was considered to be most accurate based on the analyses performed. The COD Method is comparable to the Molar Method, however it is believed to be less accurate, because in addition to biogas production and $\mathrm{CH}_{4}$ concentration, it requires representative VS and COD data from the influent stream, which is a sampling and analysis challenge. The Biodegradability Method can be the most convenient and useful method to use, since it only needs information about the anaerobic digester influent; specifically, the proportion of food waste-to-total influent added the digester (VS basis) and the influent VS.
The influent VS can vary considerably in manure-based, multi-stream AcoD systems; however, this variation is primarily dictated by the proportion of food waste or other codigestion materials fed, since the VS of the base feedstock (e.g., dairy manure) is fairly constant. The VS and COD characterization of the different food wastes brought to the AcoD system are usually provided by the suppliers, thereby all the information required to implement the Biodegradability method is readily available. Also, although not validated against measured data, the accuracy of this method is comparable to the Molar and COD methods, which are considered accurate because both use measured data of an active anaerobic digester. Furthermore, the simplified Biodegradability method has the unique advantage that it can be used for the design of new AcoD systems and long-term post-digestion storage structures - when no adequate biogas or effluent data exist.

\section{ACKNOWLEDGEMENTS}

This material is based upon work that is supported by the National Institute of Food and Agriculture, U.S. Department of Agriculture, under award number 2016-68003-24601 and the Cornell PRO-DAIRY Program via funds provided by the New York State Department of Agriculture and Markets to the Cornell Dairy Environmental Systems Program. This work was also partly funded by the Chilean Fund for Science and Technology (FONDECYT), Project 1161697. We gratefully acknowledge Jennifer L. Pronto, Cornell Dairy Environmental Systems Program team member, for her valuable work in the production of this manuscript.

\section{REFERENCES}

Antoine, C. (1888). Vapor pressure: A new relationship between pressure and temperature. CR Acad. Sci, 107, 681-685.

APHA. (2005). Standard methods for the examination of water and wastewater. Washington, DC: American Public Health Association, American Water Works Association, Water Environment Federation.

ASABE Standards. (2013). D384.2 MAR2005 (R2010): Manure production and characteristics. St. Joseph, MI: ASABE.

Batstone, D. J., Keller, J., Angelidaki, I., Kalyuzhnyi, S. V., Pavlostathis, S. G., Rozzi, A.,... Vavilin, V. A. (2002). The IWA Anaerobic Digestion Model No 1 (ADM1). Water Sci. Technol., 45(10), 65-73. https://doi.org/10.2166/wst.2002.0292

Buck, A. L. (2012). Buck Research CR-1A User's manual, appendix 1. 20-21. Boulder, CO: Buck Research Instruments, LLC.

Chai, T., \& Draxler, R. R. (2014). Root mean square error (RMSE) or mean absolute error (MAE)? - Arguments against avoiding RMSE in the literature. Geosci. Model Dev., 7(3), 1247-1250. https://doi.org/10.5194/gmd-7-1247-2014

Chen, Y. R. (1983). Kinetic analysis of anaerobic digestion of pig manure and its design implications. Agric. Wastes, 8(2), 65-81. https://doi.org/10.1016/0141-4607(83)90105-1

Chen, Y. R., \& Hashimoto, A. G. (1980). Substrate utilization kinetic model for biological treatment process. Biotechnol. Bioeng., 22(10), 2081-2095. https://doi.org/10.1002/bit.260221008

Goff, J. A., \& Gratch, S. (1946). Low-pressure properties of water from -160 to 212 F. Proc. 52nd Annual Meeting of the Am. Soc. Heating and Ventilating, (pp. 95-122). 
Gooch, C., Pronto, J., \& Labatut, R. (2011). Evaluation of seven onfarm anaerobic digestion systems based on the ASERTTI monitoring protocol: Consolidated report and findings. Biogas distributed generation systems evalustion and technology transfer - New York State Energy Research and Development Authority (NYSER-DA) Project No. 6597, Pro-Dairy Program. Ithaca, NY: Cornell University Department of Biological and Environmental Engineering.

Grady, C. P. L., Daigger, G. T., Love, N. G., \& Filipe, C. D. M. (2011). Biological wastewater treatment (3rd ed.). Boca Raton. FL: CRC Press. https://doi.org/10.1201/b13775

IWA Task Group for Mathematical Modelling of Anaerobic Digestion Processes. (2002). Anaerobic Digestion Model No.1 (ADM1). London, U.K.: IWA.

Jeris, J. S., \& McCarty, P. L. (1965). Biochemistry of methane fermentation using C14 tracers. J. Water Pollution Control Fed., 37(2), 178-192.

Kwasny, J., \& Balcerzak, W. (2016). Review - sorbents used for biogas desulfurization in the adsorption process. Polish $J$. Environ. Stud., 25(1), 37-43. https://doi.org/10.15244/pjoes/60259

Labatut, R. A. (2012). Anaerobic biodegradability of complex substrates: Performance and stability at mesophilic and thermophilic conditions. PhD diss. Ithaca, NY: Corenell University, Biological and Environmental Engineering.

Labatut, R. A. (2013). The influence of biodegradability on the anaerobic conversion of biomass into energy. In E. Dahlquist (Ed.), Sustainable energy developments: Technologies for converting biomass to useful energy (Vol. 4, pp. 325-343). Boca Raton. FL: CRC Press.

Labatut, R. A., \& Gooch, C. A. (2014). Anaerobic digestion system monitoring for the synergy biogas, LLC Biogas Plant - Final Report. Cornell Agreement No. 65961.

Labatut, R. A., Angenent, L. T., \& Scott, N. R. (2011). Biochemical methane potential and biodegradability of complex organic substrates. Bioresour. Technol., 102(3), 2255-2264. https://doi.org/10.1016/j.biortech.2010.10.035

Labatut, R. A., Angenent, L. T., \& Scott, N. R. (2014). Conventional mesophilic vs. thermophilic anaerobic digestion: A trade-off between performance and stability? Water Res., 53, 249-258. http://dx.doi.org/10.1016/j.watres.2014.01.035

Madigan, M. T., Bender, K. S., Buckley, D. H., Sattley, W. M., \& Stahl, D. A. (2017). Brock biology of microorganisms (15th ed.). London, U.K.: Pearson Publ.

McCarty, P. L. (1964). Anaerobic waste treatment fundamentals Part 1. Chemistry and microbiology. Public Works, 95(3), 107112.
McCarty, P. L. (1972). Energetics of organic matter degradation. In R. Mitchell (Ed.), Water pollution microbiology (pp. 91-118).

Owen, W. F., Stuckey, D. C., Healy, J. B., Young, L. Y., \& Mccarty, P. L. (1979). Bioassay for monitoring biochemical methane potential and anaerobic toxicity. Water Res., 13(6), 485-492. https://doi.org/10.1016/0043-1354(79)90043-5

Richards, B. K., Cummings, R. J., White, T. E., \& Jewell, W. J. (1991). Methods for kinetic analysis of methane fermentation in high solids biomass digesters. Biomass Bioenergy, 1(2), 65-73. https://doi.org/10.1016/0961-9534(91)90028-B

Ryckebosch, E., Drouillon, M., \& Vervaeren, H. (2011). Techniques for transformation of biogas to biomethane. Biomass Bioenergy, 35(5), 1633-1645. https://doi.org/10.1016/j.biombioe.2011.02.033

Speece, R. E. (2008). Anaerobic biotechnology and odor/corrosion control for municipalities and industries. Nashville, TN: Archae Press.

Stromberg, S., Nistor, M., \& Liu, J. (2014). Towards eliminating systematic errors caused by the experimental conditions in Biochemical Methane Potential (BMP) tests. Waste Manag., 34(11), 1939-1948. https://doi.org/10.1016/j.wasman.2014.07.018

Symons, G. E., \& Buswell, A. M. (1933). The methane fermentation of carbohydrates. J. Am. Chem. Soc., 55(5), 20282036. https://doi.org/10.1021/ja01332a039

Tchobanoglous, G., Stensel, H. D., Tsuchihashi, R., Burton, F., Abu-Orf, M., Bowden, G., \& Pfrang, W. (2014). Metcalf $\mid \&$ Eddy - AECOM - Wastewater engineering treatment and resource recovery (5th ed.). New York, NY: McGraw-Hill Education.

Vardanjan, R., Laizans, A., Andris Jakovics, A., \& Gendelis, S. (2015). Biogas specific heat capacity variations during upgrading. Engineering for rural development. Jelgava: University of Latvia.

Vomel, H. (2014). Saturation vapor pressure formulations. Boulder: University of Colorado. Retrieved from http://cires.colorado.edu/ voemel/vp.html

WEF/ASCE/EWRI. (2010). Design of municipal wastewater treatment plants - WEF manual of practice number 8 / ASCE manuals and reports on engineering practice number 76 . New York, NY: WEF Press - McGraw Hill.

Weiland, P. (2010). Biogas production: Current state and perspectives. Appl. Microbiol. Biotechnol., 85(4), 849-860. https://doi.org/10.1007/s00253-009-2246-7 